\title{
Microbiota de la leche humana y su impacto en la salud
} humana

Rebeca I. González-Rodríguez¹, Irma Jiménez-Escobar² y Pedro Gutiérrez-Castrellón 3,4*

${ }^{1}$ Centro de Atención Metabólica Integral del Niño y el Adolescente; ${ }^{2}$ Dirección Médica, Centro de Investigación Translacional en Ciencias de la Salud, Hospital General Dr. Manuel Gea González; ${ }^{3}$ Centro de Investigación Translacional en Ciencias de la Salud, Hospital General Dr. Manuel Gea González; ${ }^{4}$ Sociedad Latinoamericana de Gastroenterología, Hepatología y Nutrición Pediátrica. Ciudad de México, México

\section{Resumen:}

La leche materna es un fluido biológico complejo, ya que además de nutrir, contiene diversos elementos bioactivos relacionados con el fenómeno de programación metabólica temprana e incluso contiene estructuras moleculares relacionadas con el proceso de señalización epigenética tales como los microARN. Ahora sabemos que la leche humana no es estéril y contiene una diversidad significativa de microorganismos tales como bacterias (bacterioma), virus (viroma) y hongos (micobioma), todo lo cual integra el concepto de microbiota de leche humana. Al parecer el origen de esta microbiota se encuentra en la circulación enteromamaria, así como en la circulación retrógrada de la piel de glándula mamaria, aunque se especula en qué porcentaje la microbiota de la cavidad bucal del lactante contribuye de forma significativa. Desde el punto de vista funcional, se ha demostrado transferencia de esta microbiota hacia el tubo digestivo del lactante, lo que se relaciona con una mejor tolerancia digestiva, menor frecuencia e intensidad de disfuncionalidades del eje cerebro-intestino-microbiota, y mejora de la inmunidad, entre otras.

PALABRAS CLAVE: Microbiota. Leche humana. Impacto.

\section{Human milk microbiota and impact on health}

\section{Abstract:}

Breast milk is a complex biological fluid. Additionally to its nutritional impact, it contains diverse bioactive elements related to early metabolic programming and molecular structures, such as microRNA related to the epigenetic signaling process. Now, we know that human milk is not sterile and contains a significant diversity of microorganisms such as bacteria (bacterioma), viruses (viroma) and fungi (mycobiome), all of which integrate the concept of the human milk microbiota. Apparently the origin of this microbiota is found in the entero-mammary circulation, as well as in the retrograde circulation of the skin of the mammary gland, although it is speculated in what percentage the microbiota of the oral cavity of the infant contributes in a significant way. From a functional point of view, it has been shown the transfer of this microbiota to the infant's digestive tract, which is related to better digestive tolerance, lower frequency and intensity of dysfunctionalities of the brain-intestine-microbiota axis, and improved immunity, among others.

KEY WORDS: Microbiota. Human milk. Impact.

Correspondencia:

*Pedro Gutiérrez-Castrellón

E-mail: programacionmetabolica@gmail.com
Gac Med Mex. 2020;156(Supl 3): S58-S66

Disponible en PubMed www.gacetamedicademexico.com 0016-3813/๑ 2020 Academia Nacional de Medicina de México, A.C. Publicado por Permanyer. Este es un artículo open access bajo la licencia CC BY-NC-ND (http://creativecommons.org/licenses/by-nc-nd/4.0/). 


\section{Antecedentes}

La leche materna humana (LMH) es un fluido fisiológico complejo, específico, universalmente conocido como la fuente óptima de nutrición posnatal para los lactantes ${ }^{1-3}$. Consiste no solo en nutrientes esenciales (vitaminas, minerales, proteínas), células, hormonas, factores inmunológicos e inmunomoduladores (citocinas, inmunoglobulina A, microARN), también de biomoléculas no nutritivas (glicoconjugados, oligosacáridos) y una amplia gama de microbios (bacterias, arqueas, virus, protozoos y hongos anaeróbicos) conocida como microbiota de la leche humana $(\mathrm{MLH})^{4-7}$.

Se ha informado que los bebés que consumen un promedio de $800 \mathrm{ml}$ de MLH por día ingieren $10^{4} \mathrm{a}$ $10^{6}$ bacterias comensales. Estas bacterias no están simplemente presentes o son transitorias, sino que son participantes transcripcionalmente activos y funcionales en la comunidad intestinal del bebé. Estas bacterias sirven como una fuente fisiológica y continua de bacterias probióticas comensales y potenciales en el intestino del bebé. Además del papel de las bacterias de la MLH en los bebés, estas bacterias también ayudan a mantener la salud materna, es decir, ayudan en la prevención de mastitis ${ }^{8-13}$.

Antes de 2003, la MLH se consideraba estéril y desprovista de microorganismos. Sin embargo, en 2003 Martin, et al. describieron la presencia de bacterias comensales y probióticas en la MLH. Utilizando técnicas dependientes del cultivo encontraron en todas las muestras un predominio de bacterias del ácido láctico, Lactobacillus gasseri y Lactobacillus fermentum. Bacterias de ácido láctico, incluyendo especies de los géneros Lactobacillus y Bifidobacterium, son de interés en cuestiones de salud humana. Se sabe que limitan el crecimiento de organismos patógenos potenciales en el tracto gastrointestinal debido a su capacidad para producir acetato y lactato a partir del metabolismo de los azúcares ingeridos. Bifidobacterium no se consideró inicialmente como una bacteria típica del ácido láctico debido a su estructura genética no relacionada, sin embargo, su hábitat se superpone con el de las bacterias del ácido láctico y producen ácido láctico como producto final de fermentación. Según la Organización de las Naciones Unidas para la Agricultura y la Alimentación (FAO)/Organización Mundial de la Salud (OMS), cepas seleccionadas de bacterias del ácido láctico con propiedades probióticas se denominan probióticos ${ }^{14-16}$.

Recientemente, y solo utilizando técnicas basadas en ADN independientes del cultivo, incluida la desnaturalización, electroforesis en gel en gradiente, electroforesis en gel en gradiente de temperatura y secuenciación de próxima generación (NGS), se han detectado géneros bacterianos adicionales. Estos incluyen los anaerobios obligados, particularmente Bifidobacterium spp., Bacteroides spp., y miembros de la clase Clostridia ${ }^{17}$.

En el primer estudio NGS de muestras de MLH, la diversidad de comunidades bacterianas, o bacteriomas, se caracterizó utilizando pirosecuenciación de 454 para apuntar al gen $16 \mathrm{~S}$ rRNA. Se encontró que los géneros más abundantes son Streptococcus, Staphylococcus, Serratia y Corynebacterium ${ }^{5}$.

En otro estudio, de Jost, et al., la NGS reveló anaerobios intestinales, incluidos Clostridia, cuyos miembros producen el metabolito butirato que ayuda a mantener la salud del colon ${ }^{11}$. La diversidad bacteriana de MLH durante el curso de la lactancia (calostro, leche transicional y madura) también se caracterizó utilizando la misma técnica. Varios microorganismos, incluyendo Streptococcus spp., Staphylococcus spp. y bacterias del ácido láctico (Weisella spp. y Leuconostoc spp.), se encontraron en todas partes; las muestras de leche madura, sin embargo, poseían géneros bacterianos adicionales que habitualmente habitan en la cavidad bucal. Se observaron patrones de diversidad bacteriana similar utilizando NGS con Illumina MiSeq ${ }^{\circledast}$, así como en dos estudios usando enfoques metagenómicos ${ }^{6,13,17-19}$.

Mientras que el amplicón 16S se aproxima a las bacterias diana, los estudios metagenómicos permiten detección de otros microorganismos como hongos, protozoos, arqueas y virus. Otra ventaja de los métodos metagenómicos es que permiten la identificación taxonómica a nivel de especie, mientras que $16 S$ solo puede identificar con seguridad organismos hasta el nivel de género. Firmicutes y Proteobacteria fueron los filos dominantes observados en ambos estudios metagenómicos y estudios de secuenciación 16S. Sin embargo, a nivel de género, la abundancia relativa de Streptococcus y Staphylococcus fue relativamente baja. Una revisión sistemática del bacterioma de la MLH utilizando técnicas independientes del cultivo ha revelado que estos dos géneros (Staphylococcus y Streptococcus) pueden ser universalmente predominantes independientemente 
de las diferencias de área geográfica o enfoque metodológico $0^{6,13,20}$.

\section{Bacterioma central de la leche}

Hunt, et al. sugirieron en 2011 que hay un bacterioma "central» de nueve géneros bacterianos, incluyendo Staphylococcus, Streptococcus, Serratia, Pseudomonas, Corynebacterium, Ralstonia, Propionibacterium, Sphingomonas y Bradyrhizobium. Las unidades taxonómicas operativas representan aproximadamente la mitad de la comunidad microbiana observada, aunque su abundancia relativa variaba bastante significativamente entre las mujeres $^{5}$. Desde entonces, varios estudios han confirmado la hipótesis de un bacterioma central. Este «núcleo» no fue observado en muestras de calostro, lo que sugiere que la adquisición de un perfil microbiano estable es gradual ${ }^{13,19,21,22}$.

El bacterioma central puede consistir en especies necesarias para mantener una homeostasis eficiente del ecosistema cuya pérdida (o ganancia) puede afectar negativamente la estructura y función de otros miembros del ecosistema. Curiosamente, sin embargo, se supone que el núcleo de las bacterias se ven menos afectadas por los factores ambientales (dieta, obesidad, estrés) que son conocidos por alterar la composición del otro bacterioma ${ }^{23,24}$.

Se han informado diferencias en este bacterioma «central» en varios estudios $5,19,21$. Estas diferencias podrían ser el resultado de los siguientes factores: métodos de recolección de muestras (bomba eléctrica vs. expresión manual, limpieza cutánea vs. descontaminación), uso de diferentes kits de extracción de ADN, condiciones de almacenamiento y ciclos de congelación/descongelación de muestras, plataformas de secuenciación, posibles sesgos introducidos por el uso de cebadores con la amplificación de diferentes regiones hipervariables del gen de ARNr $16 \mathrm{~S}$ y el uso de diferentes tuberías en el análisis de lecturas de secuencia. A pesar de estos factores, los géneros de bacterias centrales identificados comúnmente incluían Staphylococcus, Streptococcus, Lactobacillus y Propionibacterium ${ }^{6,21}$.

\section{Origen del microbioma de la leche materna humana}

Ha habido varios debates sobre el origen de las comunidades bacterianas en MLH. En 2003, Martin, et al. utilizaron la reacción en cadena de la polimerasa (PCR) de ADN polimórfico amplificado aleatoriamente para analizar las bacterias del ácido láctico de MLH, piel de la mama y areola. Se observó que las bacterias del ácido láctico aisladas de MLH tenían perfiles de ADN diferentes de los aislados de la piel del pecho o de la areola mamaria ${ }^{14}$. También se han aislado de MLH anaerobios obligados (Bacteroides spp. y/o Bifidobacterium spp.) que es poco probable que sobrevivan a las condiciones aeróbicas de la piel de la mama ${ }^{12,21}$.

Además, un experimento realizado por Hunt, et al. en 2011 mostró que aunque el bacterioma en la piel sebácea y la MLH comparten muchos de los mismos filotipos, se encontraron diferencias. Streptococcus, uno de los géneros más abundantes en las muestras de MLH a nivel mundial, fue solo un componente menor del bacterioma cutáneo sebáceo. Propionibacterium, por otro lado, reportado como uno de los géneros más abundantes en piel sebácea, no se encontraba entre los géneros más abundantes encontrados en muestras de $\mathrm{MLH}^{5}$. El bacterioma encontrado en MLH usando Illumina MiSeq ${ }^{\circledR}$ era distinto de la piel areolar tanto en composición como en diversidad ${ }^{25}$.

Es posible que algunas bacterias que se encuentran en MLH provengan de la transferencia de bacterias de la piel y la boca que ingresan a los conductos mamarios durante la succión en un proceso llamado flujo retrógrado. Esta hipótesis fue investigada por Ramsay, et al., que utilizaron imágenes de ultrasonido para demostrar que hay un alto grado de flujo retrógrado de leche desde la boca de los bebés en los conductos mamarios durante la lactancia, lo que proporciona una ruta para el intercambio de bacterias de regreso a los conductos mamarios. Streptococcus, uno de los géneros bacterianos más abundantes en el bacterioma de la LMH, también domina el bacterioma de la saliva, prestando apoyo al mecanismo de flujo retrógrado, sin embargo, la investigación sobre si ambas comunidades bacterianas comparten especies y cepas idénticas de Streptococcus spp. está justificada ${ }^{26,27}$.

Otra hipótesis más reciente sobre el origen del bacterioma de la MLH es la vía enteromamaria, donde las bacterias no patógenas, derivadas del intestino, pueden ser transportadas a otros lugares, como las superficies mucosas de la glándula mamaria lactante a través de la vía celular endógena conocida como células mononucleares. La translocación de las bacterias intestinales a las glándulas mamarias es ayudada por los factores fisiológicos y cambios 
hormonales durante el final del embarazo y el aumento de la permeabilidad del revestimiento epitelial del intestino. En apoyo de esta hipótesis, los estudios en animales han demostrado un aumento en la translocación bacteriana de organismos aeróbicos y anaeróbicos desde el intestino a los ganglios linfáticos mesentéricos y glándulas mamarias en ratones gestantes y lactantes. Adicionalmente, Zhou, et al. han encontrado firmas bacterianas similares en las células dendríticas (CD), la leche materna (LM), intestinos y ganglios linfáticos de ratones lactantes, lo que sugiere la translocación de bacterias de los intestinos por las $C D$, en el sistema linfático y llevado a través del entorno de la glándula mamaria ${ }^{27-29}$.

Finalmente, se ha determinado recientemente el bacterioma del tejido mamario humano de biopsias de tejido recolectadas de diferentes sitios dentro de la mama. La viabilidad de las bacterias fue confirmada por cultivo. Como en el bacterioma de la LMH, el principal filo, Proteobacteria, fue el principal filo detectado en el bacterioma del tejido mamario humano. Además, las dos comunidades microbianas comparten varios géneros de bacterias. El bacterioma ductal mamario recientemente se ha descrito analizando el líquido aspirado del pezón (NAF). El NAF se secreta regularmente por las células epiteliales que recubren los conductos mamarios que se pueden recolectar de forma no invasiva del conducto en la mayoría de las mujeres aplicando presión negativa con una jeringa unida a una taza de succión. El conducto está en constante comunicación con el entorno externo a través de la areola. Es probable que haya interacción de microbios entre estos diversos compartimentos en el medio mamario ${ }^{30-33}$.

\section{Factores modificadores del microbioma de la leche materna humana (MMLH)}

Se han identificado muchos factores que contribuyen a la variabilidad de la comunidad bacteriana del MMLH entre diferentes mujeres y dentro de la misma mujer mientras experimenta diferentes condiciones fisiológicas, hormonales y patológicas. Se ha demostrado que ambos factores, maternos e infantiles, contribuyen a esta variación.

- Modo de parto: una estimación de PCR cuantitativa afirma que las mujeres que dieron a luz por cesárea (CS) tiene una abundancia menor de Lactobacillus spp. (L. fermentum y L. salivarius) y Bifidobacterium spp. en comparación con los recuentos bacterianos más altos de las mujeres que dieron a luz por vía vaginal. La MLH de las madres que tuvieron CS electiva también mostró una disminución de los miembros de la familia Leuconostocaceae y aumento de Carnobacteriaceae, en comparación con mujeres que dieron a luz por vía vaginal. Sin embargo, en un estudio de Urbaniak, et al. que utilizó un análisis estadístico más robusto no se observó diferencias en los perfiles bacterianos entre las mujeres que dieron a luz por vía vaginal y las que dieron a luz vía CS de emergencia. Se sugirió que esto podría deberse al inicio del proceso de parto, incluyendo estrés fisiológico y señales hormonales que pueden influir en el aumento de la permeabilidad del revestimiento epitelial intestinal para la translocación ${ }^{18,19,34,35}$.

- Peso materno: niveles más elevados de Staphylococcus spp. y niveles inferiores de Bifidobacterium spp. se observaron en MLH de madres con sobrepeso en comparación con las madres de peso normal, y una comunidad bacteriana menos diversa también se ha observado en madres obesas. Esto puede deberse a la capacidad metabólica del bacterioma de las personas obesas, que tiene una mayor capacidad de recolectar energía de la dieta ${ }^{18,36,37}$.

- Antibióticos y quimioterapia: menor abundancia de lactobacilos y bifidobacterias fueron reportados en MLH de madres expuestas a antibióticos durante la etapa perinatal. La exposición a quimioterapia ha resultados en una reducción de los géneros Bifidobacterium, Eubacterium, Staphylococcus y Cloacibacterium ${ }^{35,38}$.

- Salud materna: Gronlund, et al. describieron que el bacterioma está influenciado por la salud materna. En su estudio, que utilizó análisis directo de PCR, las mujeres alérgicas exhibieron Bifidobacterium spp. en sus deposiciones, y sus bebés también tienen recuentos más bajos de bifidobacterias fecales. Las mujeres africanas con VIH-ARN tenían en su MLH una mayor diversidad bacteriana y una mayor abundancia de Lactobacillus spp. en comparación con los controles. Menor abundancia de Bifidobacterium spp. y el grupo Bacteroides fragilis se han detectado en MLH de mujeres con enfermedad celiaca ${ }^{39-41}$.

- Etapa de lactancia: se detectó una mayor diversidad bacteriana, pero un recuento bacteriano total más bajo y menos especies de bifidobacterias en el calostro en comparación con la MLH madura. Los recuentos de Bifidobacterium spp. 
y Enterococcus spp., junto con el total de bacterias, aumentaron a medida que avanzaba la etapa de lactancia. Sin embargo, en un estudio similar, se observó que las muestras de leche de transición poseían una mayor diversidad que el calostro y la leche madura ${ }^{18,34,42}$.

- Ubicación geográfica: los géneros bacterianos encontrados en MLH de madres españolas eran diferentes a las de las estadounidenses o las mujeres finlandesas que usaban técnicas de secuenciación con un rendimiento igualmente alto. En un estudio de Kumar, et al. las mujeres chinas tenían niveles elevados de Actinobacteria en comparación con los niveles igualmente altos de Bacteroidetes detectados en mujeres españolas ${ }^{5,18,42,43}$.

\section{Funciones potenciales del bacterioma de la leche humana materna}

- Se ha demostrado evidencia de transmisión vertical de bacterias maternas en humanos, a través de la leche, al intestino del bebé (Lactobacillus spp.). Las secuencias aisladas de heces infantiles mostraron patrones idénticos a los encontrados en sus respectivos MLH maternos, pero diferían de los perfiles encontrados en la vagina materna. Se han confirmado cepas bacterianas idénticas de Bifidobacterium (Bifidobacterium breve y Bifidobacterium longum subsp. Longum) y Lactobacillus plantarum en MLH y heces infantiles de binomio madre-hijo, lo que sugiere una transferencia vertical de la LM al bebé $12,14,21,44,45$.

- Recientemente se ha publicado evidencia de apoyo adicional para la transmisión vertical de microbios maternos. La metagenómica (shotgun) se utilizó para demostrar la transferencia de cepas específicas de Bifidobacterium spp., Ruminococcus bromii y Coprococcus que se encuentran dentro de diferentes binomios de madre e hijo. Otro estudio comparó el bacterioma fecal de los bebés amamantados, cuyo intestino está dominado por Bifidobacterium spp. y Lactobacillus spp. transmitida de MLH a la de los lactantes alimentados con fórmula, cuyo intestino está predominantemente colonizado por enterococos, enterobacterias y Clostridium difficile, un patógeno asociado con enfermedades entéricas y atópicas ${ }^{10,46,47}$.

- Los estudios in vitro muestran que Lactobacillus rhamnosus y Lactobacillus crispatus, aislados de MLH, tienen propiedades antiinfecciosas contra Staphylococcus aureus. S. aureus se ha relacionado con mastitis, infecciones nosocomiales resistentes a antibióticos e infecciones neonatales. Las cepas de lactobacilos derivados de MLH, en particular Lactobacillus salivarius CECT5713, producen no solo actividad antibacteriana in vitro, sino también un efecto protector contra Salmonella enterica serovar Cholerasuis CECT4155 en modelos animales. Esto está mediado por la inhibición de la adhesión de $S$. enterica a las mucinas y aumentando la probabilidad de supervivencia de los ratones infectados. Además, las bacterias del ácido láctico de la MLH protegen el entorno fisiológico del intestino por medio de mecanismos como la producción de ácidos orgánicos y la disminución del pH para inhibir el crecimiento de diversas bacterias facultativas $\mathrm{y}$ anaerobias ${ }^{9,48,49}$.

- Las bacterias MLH proporcionan una fuente de bifidobacterias para el intestino de los bebés. Las bifidobacterias, a su vez, activan las células $T$ reguladoras, lo que puede dar como resultado una mejor resistencia a los microorganismos patógenos. Además, se ha demostrado que el metagenoma de la leche humana contiene motivos de ADN inmunomoduladores que pueden ayudar a disminuir las respuestas inflamatorias exageradas a las bacterias colonizadoras. Las cepas probióticas derivadas de MLH, L. fermentum CECT5716 y L. salivarius CECT5713, han demostrado actividad inmunomoduladora in vitro modulando la activación de subconjuntos de células mononucleares de sangre periférica, células asesinas naturales CD8 +, células Treg y varias citocinas y quimiocinas. Este efecto no se observó con bacterias probióticas de origen no lácteo $2,6,46,50$.

- Se ha propuesto una asociación beneficiosa entre las bacterias del ácido láctico de LMH y las alergias. Por ejemplo, estudios en animales han demostrado que los lactobacilos probióticos (de origen MLH), L. gasseri junto con Lactobacillus coryniformis, disminuyen la aparición y la gravedad de las respuestas alérgicas a la proteína de la leche de vaca. Aunque un ensayo controlado aleatorizado mostró que la suplementación con probióticos en los primeros seis meses de vida no redujo el riesgo de eccema atópico, otros estudios encontraron que la 
suplementación con Lactobacillus spp. y/o Bifidobacterium spp. en las madres condujo a una reducción del eccema infantil al año y a los dos años de edad. La hipótesis de la higiene sugiere que las propiedades antialérgicas de los probióticos se deben a la regulación a la baja en la producción de citocinas Th2 al inducir una respuesta Th1. La alteración en la regulación del sistema inmunológico se considera una causa subyacente de alergias. También es interesante observar que la presencia de estreptococos viridans, uno de los grupos bacterianos dominantes en $\mathrm{LMH}$, parece ser una característica de un intestino infantil sano en contraste con el de los lactantes atópicos cuyo intestino está dominado por Klebsiella spp. Los estudios en animales han demostrado que la maduración defectuosa del sistema inmunológico en animales que carecen de interacciones huésped-microbio adecuadas durante la vida temprana los hace propensos a respuestas inmunitarias alérgicas. Esta maduración inmunitaria defectuosa se produce con la introducción de incluso una única cepa de bacterias como Bifidobacterium spp. durante la fase neonatal ${ }^{51-57}$.

- Las bacterias de la MLH son esenciales para la digestión de oligosacáridos (el cuarto componente principal de MLH). Los bebés carecen de las enzimas necesarias para digerirlos $\mathrm{y}$, en cambio, los microbios MLH ingeridos durante la alimentación los descomponen en ácidos grasos de cadena corta; este producto final también sirve como una de las principales fuentes de energía para los colonocitos. Esto es útil para una mayor absorción de nutrientes, ya que el intestino de un bebé es mucho más corto que el de los adultos, lo que conduce a un tránsito rápido de alimentos $^{42,58}$.

- El bacterioma puede tener una función antitumoral. Los estudios in vitro han demostrado que las células muertas por calor y las fracciones citoplasmáticas de Enterococcus faecalis y Staphylococcus hominis aisladas de MLH poseen actividad antitumoral contra una línea celular de cáncer de mama. Otro estudio in vitro ha demostrado la actividad terapéutica anticancerosa de las bacterias del ácido láctico, Lactococcus lactis subsp. lactis, contra el cáncer de colon ${ }^{59,60}$.

\section{Implicaciones del bacterioma de la leche materna humana en la enfermedad}

\section{Mastitis}

La mastitis de la lactancia es una afección inflamatoria de la glándula mamaria que se presenta en aproximadamente el $30 \%$ de las mujeres que amamantan. Se caracteriza por síntomas locales (calor y dolor localizados en la mama afectada, dolor, enrojecimiento, hinchazón de la mama), además de síntomas sistémicos (fiebre). También es una de las principales razones por las que se interrumpe la lactancia materna. La mastitis es una disbiosis del bacterioma caracterizada por un rápido crecimiento de bacterias patógenas oportunistas que incluyen miembros de Staphylococcus y/o Streptococcus, Corynebacterium y el agotamiento de bacterias comensales (Lactococcus y Lactobacillus). En la mastitis aguda, se dice que el recuento de bacterias de $S$. aureus aumenta en gran medida hasta aproximadamente $4.0 \log$ (10) unidades formadoras de colonias (UFC)/ml de 1.5 a $3.0 \log (10) \mathrm{UFC} / \mathrm{ml}$ en sujetos sanos. Otra especie, Staphylococcus epidermidis, que normalmente aparece en la piel y las mucosas, es un agente causal poco reconocido de mastitis de la lactancia. Esta falta de reconocimiento puede ocurrir si el médico cree que su presencia se debe a la contaminación de muestras de MLH con flora cutánea; sin embargo, estudios recientes han demostrado que juega un papel cada vez más importante ${ }^{13,61-66}$.

Se han aislado estafilococos coagulasa negativos y $S$. epidermidis en MLH de mujeres con mastitis crónica. La naturaleza crónica se debe a que $S$. epidermidis forma biopelículas y es resistente a muchos antibióticos. Estudios recientes también muestran que el metagenoma de MLH en mujeres con mastitis es diferente según el estadio/tipo de infección. Mientras que $S$. aureus fue el agente etiológico más común de mastitis aguda, se encontró que $S$. epidermidis es la bacteria más común en mastitis subaguda ${ }^{13,64}$.

Se ha observado una diversidad bacteriana reducida y riqueza de especies en MLH de mujeres con mastitis. También se observaron secuencias relacionadas con fagos en MLH de mujeres con mastitis aguda. Esto se debe a que los factores de virulencia de $S$. aureus están codificados dentro de los fagos, 
lo que facilita que las bacterias eviten el sistema inmunológico del huésped ${ }^{13,66}$.

Patel, et al., en 2017, observaron que miembros del género Staphylococcus son diferencialmente abundantes en mastitis subaguda. Los genes relacionados con la quimiotaxis bacteriana y la invasión de células epiteliales, las proteínas de la motilidad bacteriana y el sistema de secreción se enriquecieron en mujeres con mastitis subaguda y aguda ${ }^{66}$.

En 2008 se publicó el primer ensayo controlado aleatorizado sobre el uso de probióticos en mujeres con mastitis. En este estudio, 20 mujeres con mastitis estafilocócica se dividieron al azar en dos grupos. Los del grupo de probióticos ingirieron diariamente $10 \mathrm{log}$ (10) UFC de L. salivarius CECT5713 y la misma cantidad de L. gasseri CECT5714 durante cuatro semanas, mientras que los del grupo de control solo ingirieron el excipiente. Ambas cepas de Lactobacillus se aislaron originalmente de la LM. El día 0, los recuentos medios de estafilococos en los grupos de probióticos y de control fueron similares (4.74 y 4.81 $\log (10) \mathrm{UFC} / \mathrm{ml}$, respectivamente), pero no se pudieron detectar lactobacilos. El día 30 , el recuento medio de estafilococos en el grupo de probióticos (2.96 log (10) UFC/ml) fue más bajo que el del grupo de control (4.79 log (10) UFC/ml). L. salivarius CECT5713 y L. gasseri CECT5714 se aislaron de las muestras de leche de 6 de las 10 mujeres del grupo de probióticos. El día 14 no se observaron signos clínicos de mastitis en las mujeres asignadas al grupo de probióticos, pero la mastitis persistió durante todo el periodo de estudio en las mujeres del grupo de control. En conclusión, L. salivarius CECT5713 y L. gasseri CECT5714 parecen ser una alternativa eficaz para el tratamiento de la mastitis infecciosa de la lactancia durante la lactancia ${ }^{67}$.

En 2010 se publicó un segundo ensayo controlado aleatorizado que comparó probióticos vs. antibióticos para el tratamiento de esta condición clínica; 352 mujeres con mastitis infecciosa fueron asignadas al azar a tres grupos. Las mujeres de los grupos $A(n=124)$ y $B(n=127)$ ingirieron diariamente 9 $\log$ (10) UFC de L. fermentum CECT5716 o L. salivarius CECT5713, respectivamente, durante tres semanas, mientras que las del grupo $C(n=101)$ recibieron la antibioterapia prescrita en sus respectivos centros de atención primaria. El día 0 , los recuentos bacterianos medios en las muestras de leche de los tres grupos fueron similares (4.35-4.47 $\log (10)$ UFC/ml) y no se pudieron detectar lactobacilos. El día 21, los recuentos bacterianos medios en los grupos de probióticos (2.61 y $2.33 \log (10)$ UFC/ml) fueron más bajos que los del grupo de control (3.28 log (10) UFC/ml). L. fermentum CECT5716 y L. salivarius CECT5713 se aislaron de las muestras de leche de mujeres en los grupos probióticos A y $B$, respectivamente. Las mujeres asignadas a los grupos de probióticos mejoraron más y tuvieron una menor recurrencia de mastitis que las asignadas al grupo de antibióticos ${ }^{65}$.

\section{Infecciones por virus de inmunodeficiencia humana}

Se ha demostrado que la MLH de las mujeres infectadas por el VIH tiene una composición bacteriana diferente en comparación con las mujeres no infectadas. Un aumento tanto de la diversidad bacteriana como de Lactobacillus spp. se ha observado con frecuencia. Por el contrario, S. hominis y $S$. ureus se redujeron significativamente en mujeres infectadas por el VIH. La reducción de estas dos especies de Staphylococcus puede deberse a las características inhibitorias de las bacterias del ácido láctico contra $S$. aureus. Además, un sistema inmunológico VIH positivo patológico o alterado podría ser una razón para los resultados observados. En un estudio similar, sin embargo, no hubo diferencias ni en la diversidad bacteriana ni en los perfiles bacterianos entre mujeres $\mathrm{VIH}$ positivas y $\mathrm{VIH}$ negativas. Las discrepancias en estos resultados se desconocen, pero podrían, sin embargo, deberse a una diferencia en la ubicación geológica, diferencias metodológicas o los pequeños tamaños de muestra utilizados en el estudio posterior ${ }^{40,68}$.

\section{Recomendaciones}

Se ha demostrado que el bacterioma desempeña un papel en la actividad antiinfecciosa, inmunomoduladora y metabólica y se sabe que está influenciado por factores maternos y socioeconómicos. Una mejor comprensión de los factores que influyen en el bacterioma MLH puede hacer posible manipular las comunidades bacterianas para mejorar los resultados de salud y desarrollo de los bebés. Por último, el bacterioma MLH puede estar asociado o causar enfermedades específicas. Recomendamos continuar realizando una investigación traslacional destinada a demostrar el papel específico de las bacterias de la LM en la enfermedad; explorar la interacción entre el 
bacterioma MLH y sus metabolitos, y su papel colectivo en la enfermedad; y evaluar las diferencias en el bacterioma MLH considerando factores como regiones socioeconómicas bajas.

\section{Financiamiento}

La presente investigación no ha recibido ninguna beca específica de agencias de los sectores público, comercial, o sin ánimo de lucro.

\section{Conflicto de intereses}

Los autores declaran no tener conflicto de intereses alguno.

\section{Responsabilidades éticas}

Protección de personas y animales. Los autores declaran que para esta investigación no se han realizado experimentos en seres humanos ni en animales.

Confidencialidad de los datos. Los autores declaran que en este artículo no aparecen datos de pacientes.

Derecho a la privacidad y consentimiento informado. Los autores declaran que en este artículo no aparecen datos de pacientes.

\section{Bibliografía}

1. Agostoni C, Braegger C, Decsi T, Kolacek S, Koletzko B, Michaelsen KF et al. Breast-feeding: A commentary by the ESPGHAN Committee on Nutrition. J Pediatr Gastroenterol Nutr. 2009;49:112-25

2. Civardi E, Garofoli F, Tzialla C, Paolillo P, Bollani L, Stronati M. Microorganisms in human milk: Lights and shadows. J Matern Fetal Neonatal Med. 2013;26:30-4

3. Fernandez L, Langa S, Martin V, Jimenez E, Martin R, Rodriguez JM. The microbiota of human milk in healthy women. Cell Mol Biol. 2013;59:31-42.

4. Aakko J, Kumar H, Rautava S, Wise A, Autran C, Bode L, et al. Human milk oligosaccharide categories define the microbiota composition in human colostrum. Benef Microbes. 2017;8:563-7.

5. Hunt KM, Foster JA, Forney LJ, Schutte UM, Beck DL, Abdo Z, et al. Characterization of the diversity and temporal stability of bacterial communities in human milk. PLoS ONE. 2011;6:e21313.

6. Ward TL, Hosid S, loshikhes I, Altosaar I. Human milk metagenome: A functional capacity analysis. BMC Microbiol. 2013:13:116.

7. Boix-Amorós A, Martinez-Costa C, Querol A, Collado MC, Mira A. Multiple approaches detect the presence of fungi in human breastmilk samples from healthy mothers. Sci Rep. 2017;7:13016.

8. Goldman AS. Evolution of immune functions of the mammary gland and protection of the infant. Breastfeed Med. 2012;7:132-42.

9. Heikkila MP, Saris PE. Inhibition of Staphylococcus aureus by the commensal bacteria of human milk. J Appl Microbiol. 2003:95:471-8.

10. Asnicar F, Manara S, Zolfo M, Truong DT, Scholz M, Armanini F, et al. Studying vertical microbiome transmission from mothers to infants by strain-level metagenomic profiling. mSystems. 2017; 2(1):e00164-16.

11. Jost T, Lacroix C, Braegger C, Chassard C. Assessment of bacterial diversity in breast milk using culture-dependent and culture-independent approaches. Br J Nutr. 2013:110:1253-62.

12. Jost T, Lacroix C, Braegger CP, Rochat F, Chassard C. Vertical mother-neonate transfer of maternal gut bacteria via breastfeeding. Environ Microbiol. 2014:16:2891-904.
13. Jimenez E, de Andres J, Manrique M, Pareja-Tobes P, Tobes R, Martinez-Blanch JF, et al. Metagenomic analysis of milk of healthy and mastitis-suffering women. J Hum Lact. 2015;31:406-15.

14. Martin R, Langa S, Reviriego C, Jiminez E, Marin ML, Xaus J, et al. Human milk is a source of lactic acid bacteria for the infant gut. J Pediatr. 2003:143:754-8.

15. Todar K. Important groups of procaryotes. Todar's Online Textbook of Bacteriology [Internet]. Kenneth Todar. Todar's Online Textbook of Bacteriology; 2015 [fecha de consulta: 15 de septiembre de 2018]. Disponible en: http://textbookofbacteriology.net/

16. Mohania D, Nagpal R, Kumar M, Bhardwaj A, Yadav M, Jain S, et al. Molecular approaches for identification and characterization of lactic acid bacteria. J Dig Dis. 2008;9:190-8.

17. Fouhy F, Ross RP, Fitzgerald GF, Stanton C, Cotter PD. Composition of the early intestinal microbiota: Knowledge, knowledge gaps and the use of high-throughput sequencing to address these gaps. Gut Microbes. 2012;3:203-20.

18. Cabrera-Rubio R, Collado MC, Laitinen K, Salminen S, Isolauri E, Mira A. The human milk microbiome changes over lactation and is shaped by maternal weight and mode of delivery. Am J Clin Nutr. 2012;96:544-51.

19. Urbaniak C, Angelini M, Gloor GB, Reid G. Human milk microbiota profiles in relation to birthing method, gestation and infant gender. Microbiome. 2016:4:1

20. Fitzstevens JL, Smith KC, Hagadorn JI, Caimano MJ, Matson AP, Brownell EA. Systematic review of the human milk microbiota. Nutr Clin Pract. 2017:32(3):354-64.

21. Murphy K, Curley D, O'Callaghan TF, O'Shea CA, Dempsey EM, O'Toole PW, et al. The composition of human milk and infant faecal microbiota over the first three months of life: A pilot study. Sci Rep. 2017:7:40597.

22. Jimenez E, Delgado S, Fernandez L, Garcia N, Albujar M, Gomez A, et al. Assessment of the bacterial diversity of human colostrum and screening of staphylococcal and enterococcal populations for potential virulence factors. Res Microbiol. 2008:159:595-601.

23. Shetty SA, Hugenholtz F, Lahti L, Smidt H, de Vos WM. Intestinal microbiome landscaping: Insight in community assemblage and implications for microbial modulation strategies. FEMS Microbiol Rev. 2017; 41:182-99.

24. Salonen A, Salojarvi J, Lahti L, de Vos WM. The adult intestinal core microbiota is determined by analysis depth and health status. Clin Microbiol Infect. 2012;18:16-20.

25. Pannaraj PS, Li F, Cerini C, Bender JM, Yang S, Rollie A, et al. Association between breast milk bacterial communities and establishment and development of the infant gut microbiome. JAMA Pediatr. 2017; 171:647-54.

26. Ramsay DT, Kent JC, Owens RA, Hartmann PE. Ultrasound imaging of milk ejection in the breast of lactating women. Pediatrics. 2004; 113:361-7.

27. Rodriguez JM. The origin of human milk bacteria: Is there a bacterial entero-mammary pathway during late pregnancy and lactation? Adv Nutr. 2014;5:779-84.

28. Perez PF, Dore J, Leclerc M, Levenez F, Benyacoub J, Serrant P, et al. Bacterial imprinting of the neonatal immune system: Lessons from maternal cells? Pediatrics. 2007;119:e724-e732.

29. Zhou X, Voigt A, Paveglio S, Weinstock G, Matson A, Davidovics Z Similar bacterial signatures in intestinal tissues, milk, and dendritic cells of lactating mice suggest a possible entero-mammary pathway. Gastroenterology. 2017;152:S172.

30. Urbaniak C, Cummins J, Brackstone M, Macklaim JM, Gloor GB, Baban CK, et al. Microbiota of human breast tissue. Appl Environ Microbiol. 2014;80:3007-14

31. Hieken TJ, Chen J, Hoskin TL, Walther-Antonio M, Johnson S, Ramaker S, et al. The microbiome of aseptically collected human breast tissue in benign and malignant disease. Sci Rep. 2016;6:30751.

32. Chan AA, Bashir M, Rivas MN, Duvall K, Sieling PA, Pieber TR, et al. Characterization of the microbiome of nipple aspirate fluid of breast cancer survivors. Sci Rep. 2016;6:28061.

33. Petrakis NL. Nipple aspirate fluid in epidemiologic studies of breast disease. Epidemiol Rev. 1993:15:188-95.

34. Khodayar-Pardo P, Mira-Pascual L, Collado MC, Martinez-Costa C. Impact of lactation stage, gestational age and mode of delivery on breast milk microbiota. J Perinatol. 2014:34:599-605.

35. Soto A, Martin V, Jimenez E, Mader I, Rodriguez JM, Fernandez L. Lactobacilli and bifidobacteria in human breast milk: Influence of antibiotherapy and other host and clinical factors. J Pediatr Gastroenterol Nutr. 2014;59:78-88.

36. Collado MC, Laitinen K, Salminen S, Isolauri E. Maternal weight and excessive weight gain during pregnancy modify the immunomodulatory potential of breast milk. Pediatr Res. 2012;72:77-85.

37. Turnbaugh PJ, Ley RE, Mahowald MA, Magrini V, Mardis ER, Gordon JI. An obesity-associated gut microbiome with increased capacity for energy harvest. Nature. 2006;444:1027-131.

38. Urbaniak C, McMillan A, Angelini M, Gloor GB, Sumarah M, Burton JP, et al. Effect of chemotherapy on the microbiota and metabolome of human milk, a case report. Microbiome. 2014;2:24 
39. Gronlund MM, Gueimonde M, Laitinen K, Kociubinski G, Gronroos T, Salminen S, et al. Maternal breast-milk and intestinal bifidobacteria guide the compositional development of the bifidobacterium microbiota in infants at risk of allergic disease. Clin Exp Allergy. 2007:37:1764-72.

40. Gonzalez R, Maldonado A, Martin V, Mandomando I, Fumado V, Metzner KJ, et al. Breast milk and gut microbiota in african mothers and infants from an area of high prevalence. PLoS One. 2013;8:e80299.

41. Olivares M, Albrecht S, De Palma G, Ferrer MD, Castillejo G, Schols HA, et al. Human milk composition differs in healthy mothers and mothers with celiac disease. Eur J Nutr. 2015;54:119-28.

42. Boix-Amoros A, Collado MC, Mira A. Relationship between milk microbiota, bacterial load, macronutrients, and human cells during lactation. Front Microbiol. 2016;7:492.

43. Kumar H, du Toit E, Kulkarni A, Aakko J, Linderborg KM, Zhang Y, et al. Distinct patterns in human milk microbiota and fatty acid profiles across specific geographic locations. Front Microbiol. 2016;7:1619.

44. Milani C, Mancabelli L, Lugli GA, Duranti S, Turroni F, Ferrario C, et al Exploring vertical transmission of bifidobacteria from mother to child. Appl Environ Microbiol. 2015;81:7078-87.

45. Solís G, de los Reyes-Gavilan CG, Fernández N, Margolles A, Gueimonde M. Establishment and development of lactic acid bacteria and bifidobacterial microbiota in breastmilk and the infant gut. Anaerobe. 2010;16:307-31.

46. Walker WA, lyengar RS. Breast milk, microbiota, and intestinal immune homeostasis. Pediatr Res. 2015;77:220-8.

47. Azad MB, Konya T, Maughan H, Guttman DS, Field CJ, Chari RS, et al. Gut microbiota of healthy canadian infants: Profiles by mode of delivery and infant diet at 4 months. Can Med Assoc J. 2013;185:385-94.

48. Olivares M, Díaz-Ropero MP, Martín R, Rodríguez JM, Xaus J. Antimicrobial potential of four lactobacillus strains isolated from breast milk. $J$ Appl Microbiol. 2006;101:72-9.

49. Fons AG, Tuomo Karjalainen M. Mechanisms of colonisation and colonization resistance of the digestive tract part 2: Bacteria/bacteria interactions. Microb Ecol Health Dis. 2000;12:240-6.

50. Perez-Cano FJ, Dong H, Yaqoob P. In vitro immunomodulatory activity of lactobacillus fermentum cect5716 and lactobacillus salivarius cect5713: Two probiotic strains isolated from human breast milk. Immunobiology. 2010;215:996-1004

51. Lara-Villoslada F, Olivares M, Sierra S, Rodriguez JM, Boza J, Xaus J. Beneficial effects of probiotic bacteria isolated from breast milk. Br J Nutr. 2007:98:S96-S100.

52. Taylor AL, Dunstan JA, Prescott SL. Probiotic supplementation for the first 6 months of life fails to reduce the risk of atopic dermatitis and increases the risk of allergen sensitization in high-risk children: A randomized controlled trial. J Allergy Clin Immunol. 2007;119:184-91.

53. Abrahamsson TR, Jakobsson T, Böttcher MF, Fredrikson M, Jenmalm MC, Björkstén B, et al. Probiotics in prevention of ige-associated eczema: A double-blind, randomized, placebo-controlled trial. J Allergy Clin Immunol. 2007;119:1174-80.
54. Kim JY, Kwon JH, Ahn SH, Lee SI, Han YS, Choi YO, et al. Effect of probiotic mix (bifidobacterium bifidum, bifidobacterium lactis, lactobacillus acidophilus) in the primary prevention of eczema: A double-blind, randomized, placebo-controlled trial. Pediatr Allergy Immunol. 2010; 21:e386-e393.

55. Prokopakis E, Vardouniotis A, Kawauchi H, Scadding G, Georgalas C, Hellings $P$, et al. The pathophysiology of the hygiene hypothesis. Int $J$ Pediatr Otorhinolaryngol. 2013;77:1065-71.

56. Kirjavainen PV, Apostolou E, Arvola T, Salminen SJ, Gibson GR, Isolauri E. Characterizing the composition of intestinal microflora as a prospective treatment target in infant allergic disease. FEMS Immunol. Med Microbiol. 2001;32:1-7.

57. Rautava S. Early microbial contact, the breast milk microbiome and child health. J Dev Orig Health Dis. 2016;7:5-14.

58. Maldonado J, Lara-Villoslada F, Sierra S, Sempere L, Gómez M, Rodriguez JM, et al. Safety and tolerance of the human milk probiotic strain lactobacillus salivarius cect5713 in 6-month-old children. Nutrition. 2010;26:1082-7.

59. Hassan Z, Mustafa S, Rahim RA, Isa NM. Anti-breast cancer effects of live, heat- killed and cytoplasmic fractions of enterococcus faecalis and staphylococcus hominis isolated from human breast milk. In Vitro Cell Dev Biol Anim. 2016:52:337-48.

60. Kim JY, Woo HJ, Kim YS, Kim KH, Lee HJ. Cell cycle dysregulation induced by cytoplasm of lactococcus lactis ssp lactis in snuc2a, a colon cancer cell line. Nutr Cancer. 2003;46:197-201.

61. Delgado S, Arroyo R, Martin R, Rodriguez JM. Pcr-dgge assessment of the bacterial diversity of breast milk in women with lactational infectious mastitis. BMC Infect Dis. 2008;8:51.

62. Foxman B, D'Arcy H, Gillespie B, Bobo JK, Schwartz K. Lactation mastitis: Occurrence and medical management among 946 breastfeeding women in the united states. Am J Epidemiol. 2002;155:103-14.

63. Cullinane M, Amir LH. In response to "microbial diversity in milk of women with mastitis: Potential role of coagulase-negative staphylococci, viridans group streptococci, and corynebacteria" J Hum Lact. 2017; 33:815-6.

64. Delgado S, Arroyo R, Jimenez E, Marin ML, del Campo R, Fernandez L, et al. Staphylococcus epidermidis strains isolated from breast milk of women suffering infectious mastitis: Potential virulence traits and resistance to antibiotics. BMC Microbiol. 2009:9:82.

65. Arroyo R, Martín V, Maldonado A, Jiménez E, Fernández L, Rodríguez JM. Treatment of infectious mastitis during lactation: Antibiotics vs. oral administration of lactobacilli isolated from breast milk. Clin Infect Dis. 2010;50:1551-8.

66. Patel SH, Vaidya YH, Patel RJ, Pandit RJ, Joshi CG, Kunjadiya AP. Culture independent assessment of human milk microbial community in lactational mastitis. Sci Rep. 2017;7:7804

67. Jiménez E, Fernández L, Maldonado A, Martín R, Olivares M, Xaus J, et al. Oral administration of Lactobacillus strains isolated from breast milk as an alternative for the treatment of infectious mastitis during lactation. Appl Environ Microbiol. 2008;74:4650-5.

68. Bender JM, Li F, Martelly S, Byrt E, Rouzier V, Leo M, et al. Maternal HIV infection influences the microbiome of hiv uninfected infants. Sci Transl Med. 2016;8:100-349. 